\title{
Formulation, in vitro drug release and in vivo human X-ray investigation of polysaccharide based drug delivery systems for targeting 5 -fluorouracil to the colon
}

\author{
Sidramappa Mallikarjun Chickpetty*, Baswaraj Veerappa Raga
}

KRE society’s Karnataka College of Pharmacy, Bidar, Karnataka, India

\begin{abstract}
The purpose of this research study was to develop 5-fluorouracil compression coated tablets by using biodegradable polysaccharide polymer locust bean gum (LBG) and hydroxyl propyl methyl cellulose (HPMC) as coating materials. The fast disintegrating core tablets containing $50 \mathrm{mg}$ of 5 -fluorouracil were compression coated with LBG and HPMC in different ratios (8:1, 7:2 and 6:3) with a coat weight of 300, 400 and $500 \mathrm{mg}$. In vitro dissolution data indicated that the formulation (CLH63) with a coat weight of 500 $\mathrm{mg}$ containing LBG and HPMC in the ratio $6: 3$ gave the best release profile $(0 \%$ in first 5 hour and $96.18 \%$ in 24 hours). DSC and FTIR results indicated no possibility of interaction between drug and polymers or other excipients. In vivo human X-ray studies revealed that formulation CLH63 was able to resist breakdown in the stomach and small intestine. The disintegration of the tablet occurred in the colon between 8 to 16 hours of post dose. By the present study, it can be concluded that the LBG and HPMC based compression coated tablets of 5-fluorouracil will be useful strategy for colonic delivery of 5-fluorouracil without being released in upper gastrointestinal region for the safe and effective management of colon cancer.
\end{abstract}

Uniterms: Compression coated tablet. Locust bean gum. Colon targeting. 5-fluorouracil. Colon cancer and X-ray.

O propósito desta pesquisa foi desenvolver comprimidos revestidos de fluoruracila utilizando polissacarídio biodegradável polymer locust bean gum (LBG) e hidroxipropilmetil celulose (HPMC) como materiais de revestimento. Os comprimidos de desintegração rápida contendo $50 \mathrm{mg}$ de fluoruracila foram revestidos por compressão com LBG e HPMC em diferentes proporções (8:1, 7:2 e 6:3), com peso de cobertura de 300,400 e $500 \mathrm{mg}$. Os dados da dissolução in vitro indicaram que a formulação (CLH63) com peso de cobertura de $500 \mathrm{mg}$ contendo LBG e HPMC na proporção de 6:3 forneceu o melhor perfil de liberação ( $0 \%$ nas primeiras 5 horas e $96,18 \%$ em 24 horas). Os resultados de DSC e de FTIR não indicaram interação entre o fármaco e os polímeros ou outros excipientes. Os estudos de raios $\mathrm{X}$ in vivo revelaram que a formulação CLH63 foi capaz de resistir à quebra no estômago e no intestino delgado. A desintegração do comprimido ocorreu no cólon, entre 8 e 16 horas após a administração da dose. Pelo presente estudo, concluiu-se que os comprimidos de fluoruracila revestidos com LBG e HPMC por compressão se constituirão em estratégia útil na liberação de fluoruracila no cólon, para o tratamento seguro e efetivo do câncer de cólon, sem que o fármaco seja liberado na região gastrointestinal superior.

Unitermos: Comprimido de revestimento por compressão. Locust bean gum. Direcionamento para o cólon. Fluoruracila. Câncer de colon e raios X.

\section{INTRODUCTION}

Colon-specific drug delivery systems (CDDS) have attracted a great deal of interest recently for safe

*Correspondence: Sidramappa M. Chickpetty. Department of Pharmaceutics, K.R.E.Society's Karnataka College of Pharmacy, Bidar-585403, Karnataka, India. E-mail: smc_pharma3102002@yahoo.com and effective therapy for the local treatment of colonic disorders such as Crohn's diseases, infectious diseases, irritable bowel syndrome, ulcerative colitis and colon cancer (Samia et al., 2007; Akhgari et al., 2009). Drug targeting to colon would also be useful when a delay in drug absorption is desired from therapeutic point of view, such as treatment of diseases that have peak symptoms in the early morning like nocturnal asthma, angina or 
arthritis (Valluri et al., 2008). Further it is found to be a promising site for systemic absorption of peptide and proteins. This is because the peptide and protein drugs gets destroyed or inactivated in acidic environment of the stomach or by pancreatic enzymes in the small intestine (Chellan et al., 2002). Colonic drug delivery may be achieved by either oral or rectal administration (Mayur et al., 2009). Conventional oral dosage forms are ineffective in delivering drugs to the colon due to absorption and /or degradation of the active ingredient in the upper part of the gastrointestinal tract (GIT). Rectal dosage forms (enemas and suppositories) are not always much effective due to high variability in the distribution of drug administered by this route (Sinha et al., 2004). Therefore, colon-specific drug delivery systems, which can deliver drugs to the lower gastrointestinal tract without releasing them in the upper part of GI tract, can be expected to decrease the side-effects of the drug and improve the quality of life for the patients suffering from colon-specific diseases (Samia et al., 2007).

The various approaches that have been studied for targeting orally administered drugs to the colon include use of $\mathrm{pH}$ sensitive polymers, time dependent dosage forms and the use of carriers degraded by the enzymes produced by colonic bacteria (Ashford et al, 1993; Rama Prasad et al., 1998). Of these approaches, the use of materials that are degraded by the colonic microflora has been found to be the most promising because of their site specificity (Potts et al., 1999). Because of the presence of biodegradable enzymes only in the colon, the use of biodegradable polymers for colon specific drug delivery seems to be a more site-specific approach as compared to other approaches. These polymers shield the drug from the environment of stomach and small intestine and are able to deliver the drug to the colon. On reaching the colon, they undergo assimilation by microorganisms or degradation by enzymes or breakdown of the polymer backbone leading to a subsequent reduction in their molecular weight and thereby loss of mechanical strength. They are then unable to contain drug entity (Huang et al., 1979; Ratner et al., 1998; Park, et al., 1993).

Complicated by physiological variation in gastrointestinal condition, many Colon specific drug delivery systems (CDDS) designs reported in literature have problems. The goal of CDDS is to cut off precolon drug release and release drug right at the afflicted site. Among the strategies, compression coated systems seem to be superior in preventing premature drug release in stomach and small intestine, while beginning to release the active agents at the proximal colon. On the other hand, the compression coated systems, usually in tablet form, is convenient to manufacture, and no special coating solvents or coating equipment are needed for coating process (Baojain et al., 2007).

Colorectal cancer is a common cancer secondary only to lung cancer. 5-Fluorouracil is a pyrimidine analogue and is the drug of choice for colon cancer (Calabresi, Chabner, 1996). Usually it is administered parenterally because absorption after ingestion is unpredictable and incomplete (Hahn et al., 1975). Distribution of 5-fluorouracil to undesired sites produces severe toxic effects of the gastrointestinal, hematological, cardiac, neural and dermatological (Diasio, Harris, 1998). Targeting of 5 -fuorouracil to the colon for the treatment of colon cancer would not only reduces its systemic toxicity but would also show desired action with a reduced dose. Therefore in the present investigation, based on the physiological characteristics of the GIT, features of enzyme dependent systems and formulation strategies, it could be predicted that such functions into the single delivery systems seems to be desirable to achieve the site-specificity of drug release in the physiological environment of colon. The present research study was proposed to develop a novel biodegradable polysaccharide based compression coated tablet formulations for delivering 5 -fuorouracil into the colon by using locust bean gum as a carrier in combination with HPMC and to characterize its colon site-specificity. The developed formulation consisted of two parts, i.e., a fast disintegrating and dissoluting 5-fuorouracil core tablet and outer compression coating layer which could protect or reduce immature drug release in the upper part of gastro intestinal tract and expected to release only in the colon after oral administration due to degradation of the LBG present in the coat by the caecal enzymes action in the colon.

\section{MATERIAL AND METHODS}

\section{Material}

5-Fluorouracil batch No. 25310FU0108131 (98.0 to $102.0 \%$ pure) was given by Strides Acrolabs 1td., Bangalore, India as a gift sample. Locust bean gum was obtained as a gift sample from lucid colloids Pvt. Ltd., Mumbai, India. Hydroxy propyl methyl cellulose (Colorcon Asia pvt. Ltd. Goa), crosscarmellose sodium and spray dried lactose (Aurobindo pharma, Hyderabad) was obtained as a gift sample. Starch, talc and magnesium stearate (S.D. fine chem. 1td.) were obtained from the local market. All other reagents and chemicals used were of analytical reagent grade. 


\section{Methods}

\section{Preparation of 5-fluorouracil compression coated tablets}

- $\quad$ Preparation of fast disintegrating and dissoluting 5-fluorouracil core tablets

Fast disintegrating and dissoluting 5-fluorouracil core tablets (5-FLU core) were prepared by direct compression formula (Table I) by using spray dried lactose as a direct compression aid and croscarmellose sodium as super disintegrating agent. The 5-fluorouracil, crosscarmellose sodium, lactose, magnesium stearate and talc were accurately weighed and thoroughly mixed with mortar and pestle and passed through the mesh $(150 \mu \mathrm{m})$ to ensure complete mixing of all the ingredients. The uniformity of mixing was assessed by conducting content uniformity test on the sample of powder mixture. Quantity weighing $100 \mathrm{mg}$ was compressed into tablets using $6 \mathrm{~mm}$ round, flat and plain punches on a single station tableting machine (Cadmach, India).

- Preparation of 5-fluorouracil compression coated tablets:

The developed 5-fluorouracil core tablets were compression coated with a coat weight of $500 \mathrm{mg}$ (core coat ratio 1:5), $400 \mathrm{mg}$ (core coat ratio 1:4) and $300 \mathrm{mg}$ (core coat ratio 1:3) containing different ratios of LBG and HPMC. Formulae of different granular coat composition of LBG and HPMC in the ratio 8:1, 7:2 and 6:3 with various excipients were listed in Table II. For compression coating about $45 \%$ of coat weight was first placed in the die cavity followed by carefully centering the core tablet and filled with the remainder $55 \%$ of coat weight. The coating material was then compressed around the core tablet by using single-station tableting machine with $10 \mathrm{~mm}$ plain punches.

- $\quad$ Physical evaluation tests for 5-fluorouracil core and compression coated tablets

Standard physical tests for the developed 5-fluorouracil core and compression-coated tablets were performed and average values calculated. Weight variation was determined by weighing 20 tablets individually, and the average mass and percent variation of each tablet was calculated. Hardness was determined by taking 5 tablets from each batch using a Monsanto hardness tester (Electrolab Pvt. Ltd., India) and the average pressure $\left(\mathrm{kgcm}^{-2}\right)$ applied to crush the tablet was determined. Friability was tested on ten tablets by first weighing and then placing them in a Roche Friabilator, which rotated for 4 min or 100 revolutions. After dusting, the total remaining mass of the tablets was recorded and the percent friability calculated. (Lachman et al., 1987).

\section{Estimation of drug content}

The 5-fluorouracil cores as well as compression coated tablets were tested for their drug content to ensure uniformity in drug content. The 10 tablets were finely powdered, and quantity of the powder equivalent to $50 \mathrm{mg}$ of 5 -fluorouracil was accurately weighed and transferred to $100 \mathrm{~mL}$ volumetric flasks containing $50 \mathrm{~mL}$ of phosphate buffer $\mathrm{pH} 6.8$ and allowed to stand for 6 hour with intermittent shaking to ensure complete solubility of the drug. The solution then made up to $100 \mathrm{~mL}$ with phosphate buffer pH 6.8 and mixed thoroughly. The solution was filtered, diluted and drug content was estimated by UV-spectrophotometer at the $\lambda_{\text {max }} 266 \mathrm{~nm}$ (Shimadzu, Japan).

\section{In vitro dissolution studies}

- In simulated gastric and intestinal fluid

The ability of LBG polysaccharide based 5-fluorouracil compression coated tablets to protect the drug during the transit time in the gastro intestine region was assessed by mimicking mouth to colon transit. Drug release studies were carried out using USP XXIII dissolution basket method (100 rpm and $37 \pm 0.5^{\circ} \mathrm{C}$ ) in $900 \mathrm{~mL} \mathrm{pH} 1.2$ buffer solution for the first 2 hour, as the average gastric emptying time is 2 hour, then the dissolution media is replaced with $\mathrm{pH} 7.4$ phosphate buffer

TABLE I - Composition of fast disintegrating and dissoluting 5-fluorouracil core tablet

\begin{tabular}{lccc}
\hline S.No. & Ingredients & Category & Quantity/Tablet (in mg) \\
\hline 1. & 5-fluorouracil & Active ingredient & 50 \\
2. & Croscarmellose sodium & Super disintegrant & 05 \\
3. & Spray dried lactose & Direct compression aid & 42 \\
4. & Magnesium stearate & Lubricant & 02 \\
5. & Talc & Glidant & 01 \\
& Total composition & ---- & $100 \mathrm{mg} /$ tablet \\
\hline
\end{tabular}


TABLE II - Composition of granular coat formulations for compression coating on 5-fluorouracil core tablets

\begin{tabular}{|c|c|c|c|c|c|c|c|c|c|c|c|}
\hline \multirow{2}{*}{ S.No. } & \multirow{2}{*}{ Ingredients } & \multirow{2}{*}{ Category } & \multicolumn{9}{|c|}{ Quantity / Tablet (in mg) } \\
\hline & & & ALH81 & ALH72 & ALH63 & BLH81 & BLH72 & BLH63 & CLH81 & CLH72 & CLH63 \\
\hline 1. & $\begin{array}{l}\text { Locust Bean } \\
\text { gum }\end{array}$ & $\begin{array}{l}\text { Biodegradable } \\
\text { polymer }\end{array}$ & 240 & 210 & 180 & 320 & 280 & 240 & 400 & 350 & 300 \\
\hline 2. & HPMC & $\begin{array}{c}\text { Swellable } \\
\text { polymer }\end{array}$ & 30 & 60 & 90 & 40 & 80 & 120 & 50 & 100 & 150 \\
\hline 3. & $\begin{array}{l}\text { Starch } \\
\text { (Paste) }\end{array}$ & Binding agent & 24 & 24 & 24 & 32 & 32 & 32 & 40 & 40 & 40 \\
\hline 4. & $\begin{array}{l}\text { Magnesium } \\
\text { Stearate }\end{array}$ & Lubricant & 3 & 3 & 3 & 4 & 4 & 4 & 5 & 5 & 5 \\
\hline \multirow[t]{4}{*}{5.} & Talc & Glidant & 3 & 3 & 3 & 4 & 4 & 4 & 5 & 5 & 5 \\
\hline & $\begin{array}{c}\text { Total coat } \\
\text { weight }\end{array}$ & ----- & 300 & 300 & 300 & 400 & 400 & 400 & 500 & 500 & 500 \\
\hline & $\begin{array}{c}\text { LBG : } \\
\text { HPMC ratio }\end{array}$ & ----- & $8: 1$ & $7: 2$ & $6: 3$ & $8: 1$ & $7: 2$ & $6: 3$ & $8: 1$ & $7: 2$ & $6: 3$ \\
\hline & $\begin{array}{l}\text { Core : Coat } \\
\text { ratio }\end{array}$ & ---- & $1: 3$ & $1: 3$ & $1: 3$ & $1: 4$ & $1: 4$ & $1: 4$ & $1: 5$ & $1: 5$ & $1: 5$ \\
\hline
\end{tabular}

for 3 hour, as the usual small intestine transit time is 3-5 hour and dissolution was continued in phosphate buffer pH 6.8 up to 24 hour to stimulate the gastrointestinal environment as the usual colon transit time is $20-30$ hour. Samples $(5 \mathrm{~mL})$ were withdrawn and replaced with fresh medium at fixed time intervals. The sample was suitably diluted and analyzed for percentage of drug release by UV spectrophotometer at the $\lambda_{\text {max }} 266 \mathrm{~nm}$.

- In simulated rat caecal content fluid

The susceptibility of locust bean gum coat to the enzymatic action of colonic bacteria was assessed by continuing the drug release studies in presence of rat caecal contents because of its similarity to human intestinal microflora (Oluwatoyin, John, 2005). The caecal contents were obtained from male albino rats after pretreatment with $1 \mathrm{ml}$ of $2 \% \mathrm{w} / \mathrm{v}$ LBG dispersion in water using gavage for 7 days in order to induce the enzymes acting on polysaccharides. At $45 \mathrm{~min}$ before the drug release studies, rats were killed by spinal traction. Their abdomen were opened, the caecum isolated, caecal content removed, weighed and suspended in phosphate buffer ( $\mathrm{pH}$ 6.8) solution which was previously bubbled with $\mathrm{CO}_{2}$ to give a final dilution of $4 \% \mathrm{w} / \mathrm{v}$, which had been reported to provide the best conditions for assessing the susceptibility to colonic degradation (Prasad et al., 1998). Ethical clearance for the handling of experimental animals as per CPSCEA guidelines was obtained from the Institutional Animal Ethical Committee (IAEC) constituted for the purpose. The in vitro drug release studies simulating in colon were carried out in USP dissolution rate test apparatus (Apparatus 1, $100 \mathrm{rpm}$, $37 \pm 0.5^{\circ} \mathrm{C}$ ) with slight modifications as reported earlier by many researchers (Prasad et al., 1998). A beaker (capacity $250 \mathrm{~mL}$ ) containing $200 \mathrm{ml}$ of rat caecal content medium was immersed in the water maintained in $1000 \mathrm{~mL}$ vessel, which in turn, was in the water bath of the apparatus. The 5 -fluorouracil tablet formulation after completing the dissolution studies in $\mathrm{pH} 1.2$ buffer ( 2 hour) and phosphate buffer $\mathrm{pH} 7.4$ (3 hour) were placed in the basket of the apparatus and immersed in the phosphate buffer $\mathrm{pH} 6.8$ containing $4 \% \mathrm{w} / \mathrm{v}$ rat caecal conetnt contained in $250 \mathrm{~mL}$ beaker and dissolution studies continued up to 24 hour. As the cecum is naturally anaerobic, the experiment was carried out with continuous supply of carbondioxide into the beaker containing rat caecal medium. At the end of the time period $5 \mathrm{~mL}$ samples were withdrawn, suitably diluted, centrifuged to remove debris and analyzed for percentage of drug release by UV spectrophotometer at the $\lambda_{\text {max }} 266 \mathrm{~nm}$.

\section{In vivo human $x$-ray studies}

$\mathrm{X}$ ray imaging was used to monitor the tablets throughout the GI system. Two healthy human volunteers with an age group of 34-36 years and 68-70 kg body weight were recruited in the in vivo studies. Volunteers were non alcoholic, non smoker and had not taken any drugs. The purpose of the study was fully explained and volunteers had given their written consent. After an overnight fast, 
subject ingested barium sulfate containing compression coated tablets of optimized batch (based upon in vitro drug release studies) orally with $250 \mathrm{~mL}$ of water. The tablets were visualized using $\mathrm{x}$-ray. Abdominal radiographs were taken at fixed time intervals (after 2, 5, 8, 12, 16 and 20 hours) and tablets were visualized for site and time range of disintegration of tablet in the colon. The volunteers were served with light breakfast at 2 hour post-dose. This was followed by a standard lunch at 4 hour post-dose. Tea was given at 8 hour post-dose and a standard dinner was given at $12 \mathrm{~h}$ post-dose (Demiroz et al., 2004). The experimental protocol and consent for in vivo studies were approved by Institute Review Board.

\section{FTIR spectral studies}

The $\mathrm{KBr}$ pellets with neat drug 5-fluorouracil, powdered tablet formulation of optimized batch CLH63 (selected on the basis of in vitro drug release studies) before storage, after storage and placebo tablet formulation of optimized batch were prepared. A FTIR (Shimadzu, FTIR 8400 S, Japan) spectrophotometer was used to record IR spectra of the prepared pellets in the range of $400-4000 \mathrm{~cm}^{-1}$ with a resolution of $1 \mathrm{~cm}^{-1}$ to confirm the absence of chemical interaction of 5-fluorouracil with excipients of core as well as compression coated tablets.

\section{Differential scanning colorimetric studies}

The possibility of any interaction between 5 -fluorouracil and locust bean gum or other excipients used in the formulation during tablet processing was further assessed by carrying out the thermal analysis on pure drug 5-fluorouracil, powdered tablet formulation of optimized batch CLH63 before storage and after storage at $40 \pm 2{ }^{\circ} \mathrm{C} / 75 \pm 5 \% \mathrm{RH}$ for six months by constant rate heating $(\mathrm{CRH})$ method proposed by international confederation for thermal analysis and calorimetry (ICTAC). The DSC curves of the samples were obtained at a standard scanning rate of $10^{\circ} \mathrm{C} / \mathrm{min}$ conducted over a temperature range of 0 to $350^{\circ} \mathrm{C}$.

\section{Stability Studies}

To assess the long term stability of the compression coated tablet formulations, the optimized batch formulation (CLH63) were stored at $40 \pm 2{ }^{\circ} \mathrm{C} / 75 \pm 5 \% \mathrm{RH}$ for a period of six months. Samples were observed for any physical change, compressional characteristics and drug content. At the end of six months storage study period, the initial (zero time) results were compared with post-stability testing period results. The powdered samples of 5-fluorouracil compression coated tablet formulations CLH63 were also subjected to DSC and FTIR studies.

\section{RESULTS AND DISCUSSION}

The outer coat of LBG and HPMC function as the rate controlling mechanism of 5-fluorouracil release from compression coated tablets, therefore the core tablets were prepared with fast disintegration and dissolution characteristics. Tested in USP disintegration tester (Elico, India), the core tablets were found to disintegrate within $1 \mathrm{~min}$ showing required fast disintegration characteristic and over $95 \%$ of 5 -fluorouracil dissoluted in $\mathrm{pH} 1.2$ buffer within $30 \mathrm{~min}$. The fast disintegration and dissolution of the core tablet prevent it from being the rate limiting factor for release of 5-fluorouracil from compression coated tablets soon after degradation of the biodegradable polysaccharide material locust bean gum content present in the coat by the caecal enzymes in rat caecal medium. The physical property of the 5-fluorouracil core tablet was given in Table III. The core tablet complied with pharmaceutical standards and falls within the limits of Indian pharmacopoeia for weight variation, hardness, friability and drug content uniformity.

All batches (A, B and C series) of compression coated tablets were produced under similar conditions to avoid influence of processing variables. The coated tablets of different formulations were subjected to various evaluation tests, such as hardness, friability, weight variation, drug content uniformity and in vitro dissolution. Physical evaluation results of all the formulations are shown in Table III. In a weight variation test, mass values of the coated tablets were between $1.03 \%$ and $2.90 \%$. The average percentage deviation of all tablet formulations was found to be within the limit, and hence all formulations passed the test for uniformity of weight as per official requirements. The hardness of tablets was between $5.92 \pm 0.38$ and $6.32 \pm 0.13 \mathrm{kgcm}^{-2}$. The percentage friability of all the formulations was between 0.238 and $0.447 \%$. Tablets that lose less than $1 \%$ of their weight are generally acceptable. In the present study, the percentage friability for all the formulations was below $0.5 \%$, indicating that their friability was within the prescribed limits. Values of the hardness test and percent friability indicate good handling properties of the prepared coated tablets. The drug content uniformity ranged from $98.06 \pm 3.02$ to $100.03 \pm 1.32 \%$ which ensures uniformity in drug content in all the coated formulations.

The ability of 5-fluorouracil compression coated tablets to remain intact in the physiological environment 
TABLE III - Physical evaluation study for 5-fluorouracil core and compression coated tablets

\begin{tabular}{ccccc}
\hline Formulation & $\begin{array}{c}\text { Hardness } \\
\left(\mathrm{kg} \mathrm{cm}^{-2} \pm \mathrm{SD}\right) \\
(\mathrm{n}=5)\end{array}$ & $\begin{array}{c}\text { Friability } \\
(\%) \\
(\mathrm{n}=10)\end{array}$ & $\begin{array}{c}\text { Drug Content } \\
(\% \pm \mathrm{SD}) \\
(\mathrm{n}=10)\end{array}$ & $\begin{array}{c}\text { Weight Variation } \\
(\%) \\
(\mathrm{n}=20)\end{array}$ \\
\hline 5-FLU core & $3.10 \pm 0.12$ & 0.637 & $100.89 \pm 1.58$ & 2.01 \\
ALH81 & $5.92 \pm 0.38$ & 0.334 & $99.72 \pm 2.82$ & 1.03 \\
ALH72 & $5.98 \pm 0.14$ & 0.285 & $99.58 \pm 1.51$ & 1.46 \\
ALH63 & $6.04 \pm 0.15$ & 0.397 & $100.03 \pm 1.32$ & 2.38 \\
BLH81 & $5.96 \pm 0.27$ & 0.338 & $98.19 \pm 2.72$ & 2.68 \\
BLH72 & $6.02 \pm 0.69$ & 0.238 & $98.69 \pm 2.09$ & 1.98 \\
BLH63 & $6.22 \pm 0.13$ & 0.258 & $99.27 \pm 2.03$ & 1.34 \\
CLH81 & $6.32 \pm 0.13$ & 0.331 & $98.06 \pm 3.02$ & 2.90 \\
CLH72 & $6.12 \pm 0.24$ & 0.447 & $98.91 \pm 1.83$ & 1.60 \\
CLH63 & $6.06 \pm 0.19$ & 0.298 & $99.23 \pm 1.62$ & 2.30 \\
CLH63 & $5.64 \pm 0.15$ & 0.615 & $97.75 \pm 0.89$ & 1.58 \\
\hline
\end{tabular}

* Data obtained after storage period of 6 months at $40{ }^{\circ} \mathrm{C} / 75 \% \mathrm{RH}$.

of stomach and small intestine was assessed by conducting in vitro drug release studies in $\mathrm{pH} 1.2$ buffer for 2 hours, then in phosphate buffer $\mathrm{pH} 7.4$ for 3 hours and continued in phosphate buffer $\mathrm{pH} 6.8$ up to 24 hours without and with rat caecal content in dissolution medium. The results of the in vitro drug release studies carried out on 5-fluorouracil core tablets compression coated with a combination of locust bean gum and HPMC in different ratios (8:1, 7:2 and 6:3) and coat weights (300 mg, $400 \mathrm{mg}$ and $500 \mathrm{mg}$ ) are shown in Figure 1, 2 and 3.

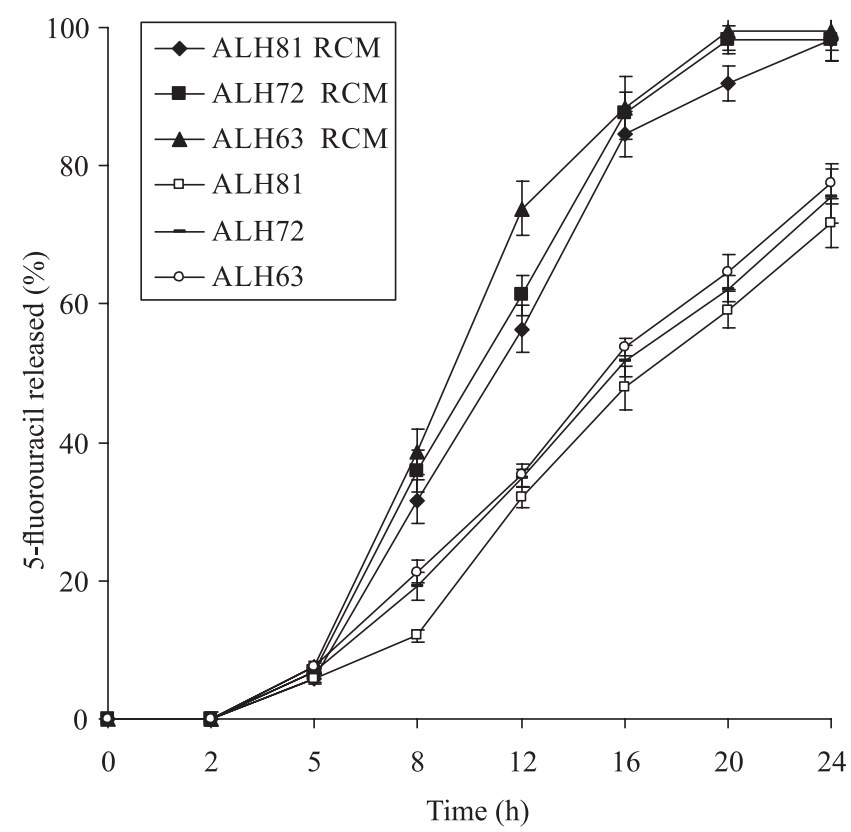

FIGURE 1 - In vitro release profile of 5-fluorouracil from formulation coated with $300 \mathrm{mg}$ without and with rat caecal medium (RCM).

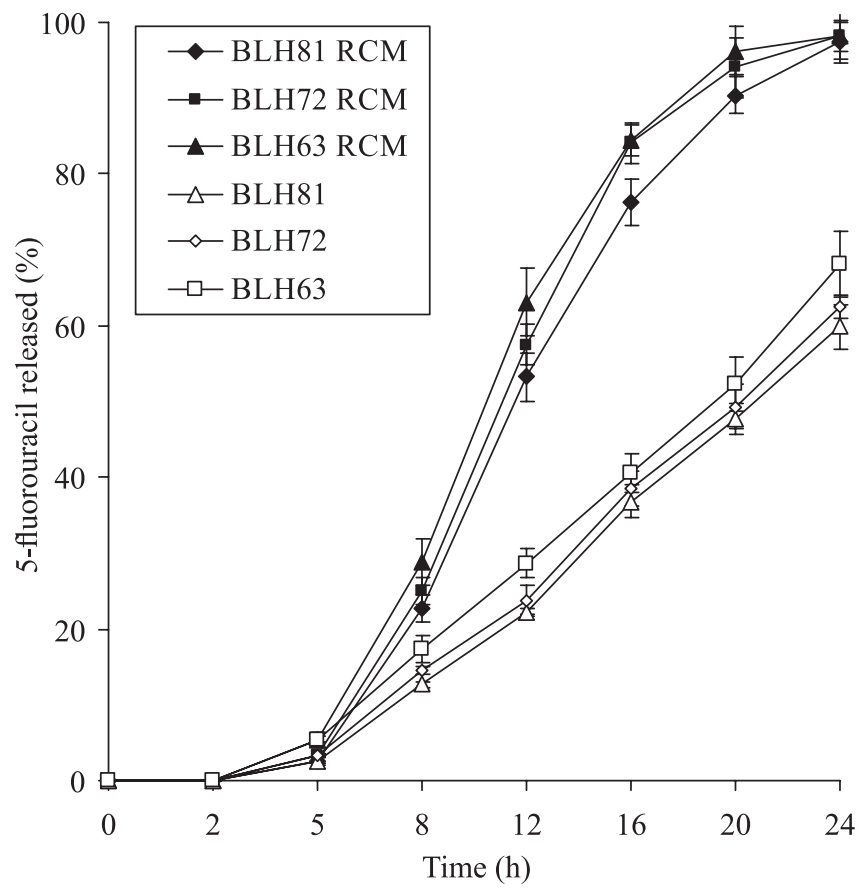

FIGURE 2 - In vitro release profile of 5-fluorouracil from formulation coated with $400 \mathrm{mg}$ without and with rat caecal medium (RCM).

The percent 5 -fluorouracil released from formulation ALH81, ALH72, ALH63, BLH81, BLH72, BLH63 was $5.85 \%, 6.92 \%, 7.52 \%, 2.59 \%, 3.36 \%, 5.42 \%$, respectively, in the first 5 hour of dissolution studies in simulated gastric ( 2 hours) and intestinal fluid ( 3 hours) as shown in Figure 1 and 2. From the release profile it was clear that all the formulations with a coat weight of 300 and $400 \mathrm{mg}$ fails to control drug release during the initial $5 \mathrm{~h}$ of dissolution studies in simulated gastric ( 2 hours) and 


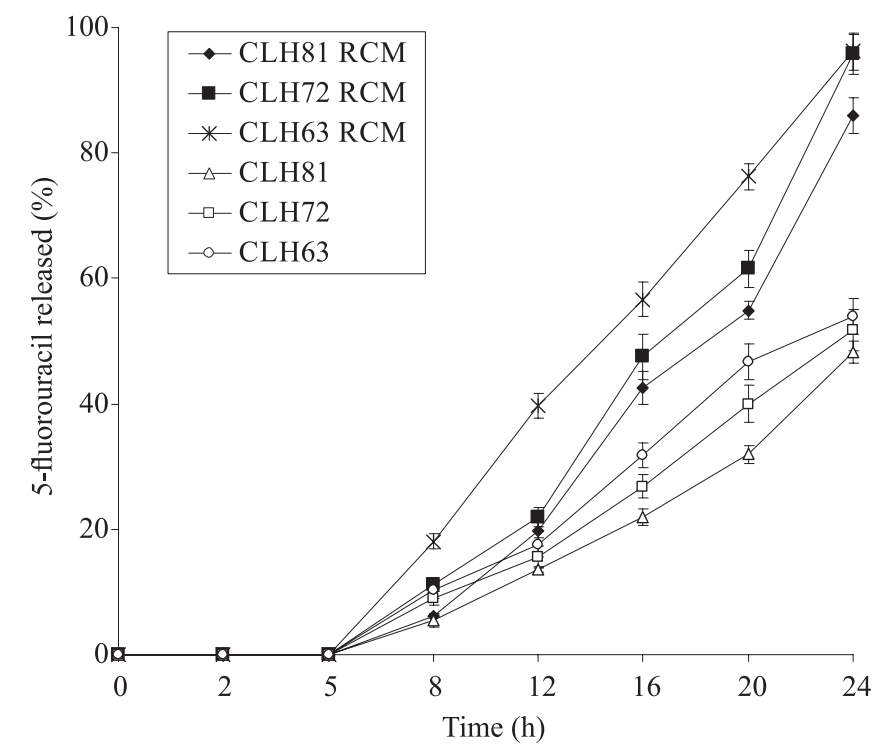

FIGURE 3 - In vitro release profile of 5-fluorouracil from formulation coated with $500 \mathrm{mg}$ without and with rat caecal medium (RCM).

intestinal fluid ( 3 hours). This may be due to the reduced coat weights ( $300 \mathrm{mg}$ and $400 \mathrm{mg}$ ) used around the 5 -fluorouracil core tablet, which might not be sufficient to form a thick viscous gel layer around the core tablet to prevent drug release in the first $5 \mathrm{~h}$ and were higher as the coat weight decreased around the core tablet. The release of drug ranging from $2.59 \%$ to $7.52 \%$ in the first 5 hours is a serious consideration for anti cancer drug like 5 -fluorouracil which shows deleterious effects on stomach and small intestine.

The oral drug delivery systems targeted to colon should protect the drug being released in the stomach and small intestine. Hence, the coat weight was increased to $500 \mathrm{mg}$ (core coat ratio 1:5) in tablets formulation CLH81, CLH72 and CLH63 as shown in Table II with an objective to prevent the initial premature drug release in upper gastrointestinal region. The formulation CLH81, CLH72 and CLH63 released no drug in the first 5 hours of dissolution study in simulated gastric and intestinal fluid as shown in Figure 3. This suggests that LBG-HPMC mixture with a coat weight of $500 \mathrm{mg}$ can effectively controls the release of the drug in the first 5 hours of dissolution studies. This might be due to high coat weight used around the core tablet and forming a viscous gel layer which retards seeping of dissolution fluid in to the core formulation and controls diffusion of drug from the core into dissolution fluid. It is clearly evident from the in vitro release data that on increasing the coat weight around the core tablet minimized the drug release in the initial 5 hours. This might be due to fact that increased coat weights forms a thick viscous gel layer around the core tablet which resulted in an increased resistance of coat to dissolution fluid, causing decreased fluid imbibition consequently causing a decrease in rate of dissolution of drug in core, and ultimately resulted in a decline in drug release.

To assess the integrity of the polysaccharide LBG coat the drug release studies were carried out without addition of rat ceacal content to $\mathrm{pH} 6.8$ phosphate buffer dissolution media. At the end of $24 \mathrm{~h}$ of dissolution study, the formulation ALH81, ALH72, ALH63, BLH81, BLH72, BLH63 CLH81, CLH72 and CLH63 were highly swollen and mean percent drug released was $71.76 \%, 75.60 \%$, $77.41 \%, 59.84 \%, 62.47 \%, 68.13 \%, 48.22 \%, 51.72 \%$, $53.94 \%$ respectively. It is evident from in vitro release data that, the drug release from all the formulations were found to be incomplete in the physiological environment of colon during the dissolution testing period of 24 hours. This indicates that the locust bean gum present in the coat is not degraded, which was expected to degrade in rat caecal medium, increasing the release of the remaining 5-fluorouracil drug present in the core tablet formulation in to the rat caecal content medium.

The percent 5-fluorouracil released in presence of $4 \%$ rat caecal content medium from formulation ALH81, ALH72, ALH63, BLH81, BLH72, BLH63, CLH81, CLH72 and CLH63 was found to be $98.16 \%, 98.27 \%$, $99.51 \% 97.52 \%, 98.16 \%, 98.34 \%, 85.94 \%, 95.73 \%$ and $96.18 \%$, respectively, at the end of 24 hour as shown in Figure 1, 2 and 3. The release profiles revealed that drug release was increased rapidly and more then $95 \%$ of the drug was released from all the formulations except CLH81 in rat caecal medium compared with that in with out rat caecal content medium. The formulation CLH81 released only $85.94 \%$ of the drug, this is due to high proportion of LBG content present in the coat shell which might have not disintegrated completely during the dissolution testing period of 24 hours in rat caecal medium. The increase in the release rate in rat caecal medium was most probably due to biodegradation of LBG present in the coat by colonic bacterial enzymes. It is evident from the Figure 1, 2 and 3 that the coat weights used for coating around the core tablet had a marked effect on drug release rate in the rat caecal content medium. As the coat weight decreases, rate of degradation of LBG in rat caecal medium increases, which caused increment of drug release from formulations. It could be seen that release rate was higher in formulation of $\mathrm{A}$ and $\mathrm{B}$ series compared with that in formulation of $\mathrm{C}$ series, where proportion of LBG or coat weight was higher. The rate of drug release was found to increase from $8 \mathrm{~h}$ in all the formulations with a coat weight of 300 and $400 \mathrm{mg}$ and in formulations with a higher coat weight of $500 \mathrm{mg}$ 
the release rate was found to increase from 12 hours. The in vitro results revealed that for protecting 5 -fluorouracil core tablet in the physiological environment of stomach and small intestine, the 5-fluorouracil core tablet should be coated with a higher coat weight $(500 \mathrm{mg})$.

In vitro release studies in the presence of rat caecal content indicated the suitability of the polysaccharide locust bean gum based compression coated tablets for colonic delivery of 5-fluorouracil in case of LBG and HPMC mixture in the ratio $6: 3$ with a coat weight of $500 \mathrm{mg}$ as coating materials. However, the evaluation of the dosage form in human renders support to in vitro studies. Hence, X-ray studies were carried out on healthy human volunteer to access the in vivo performance and to support in vitro drug release studies of the optimized batch formulation CLH63. The studies were carried out using barium sulphate as $\mathrm{X}$-ray opaque material. As per the advice of a well-known radiologist of the city, the time and amount of radiation exposed to volunteers would be more if $\gamma$-scintigraphy technique is adopted. Also $\gamma$-scintigraphy technique utilizes the radiotracers, which may harm the volunteers. Further, X-ray visualization of tablet disintegration performance has been studied by many researchers (Munira, Pundarikakshudu, 2007). Hence, it was proposed to use roentegenography technique which is comparatively safer technique. The optimized batch compression coated tablet formulation CLH63 containing barium sulphate was ingested by the health volunteers and images were taken at different time intervals. The position of the test tablet formulation throughout GI system at different time points were shown in Figure 4.

From the abdominal radiographs taken at different time intervals, it is evident that tablet remained unchanged form in the stomach and after 2 hour it is found in the jejunum as shown in Figure 4 (A). After 5 hours, the tablet appeared to be slightly swollen but remained intact and reached the ileocecal region without disintegrating in the upper region of GI tract this is due to the resistance of the coat to the stomach and intestinal fluid. The X-ray images showed that the tablets slowly disintegrated in the colon (ascending colon/hepatic flexure) after reaching colon between 5 and 8 hours of post administration. It is evidenced by reduction in swollen tablet size appeared in X-ray images taken after 8 hours, 12 hours and 16 hours. This can be attributed to a possible degradation of locust bean gum and solubilization of HPMC present in the coat in the physiological environment of colon. Complete disintegration of the tablet was seen clear after 20 hours post administration. This was attributed by the disappearance of the tablet as shown in X-ray image Figure $4(\mathrm{~F})$. These results are in agreement with the results of Ashford et al. (1993) who observed that the gastric emptying time of 0.6-2.9 hour, small intestine transit time of 1.8-8.5 hours and colonic arrival time of 3.2-9.8 hours while evaluating pectin as a compression coat for colonic drug delivery, using gamma scintigraphy.

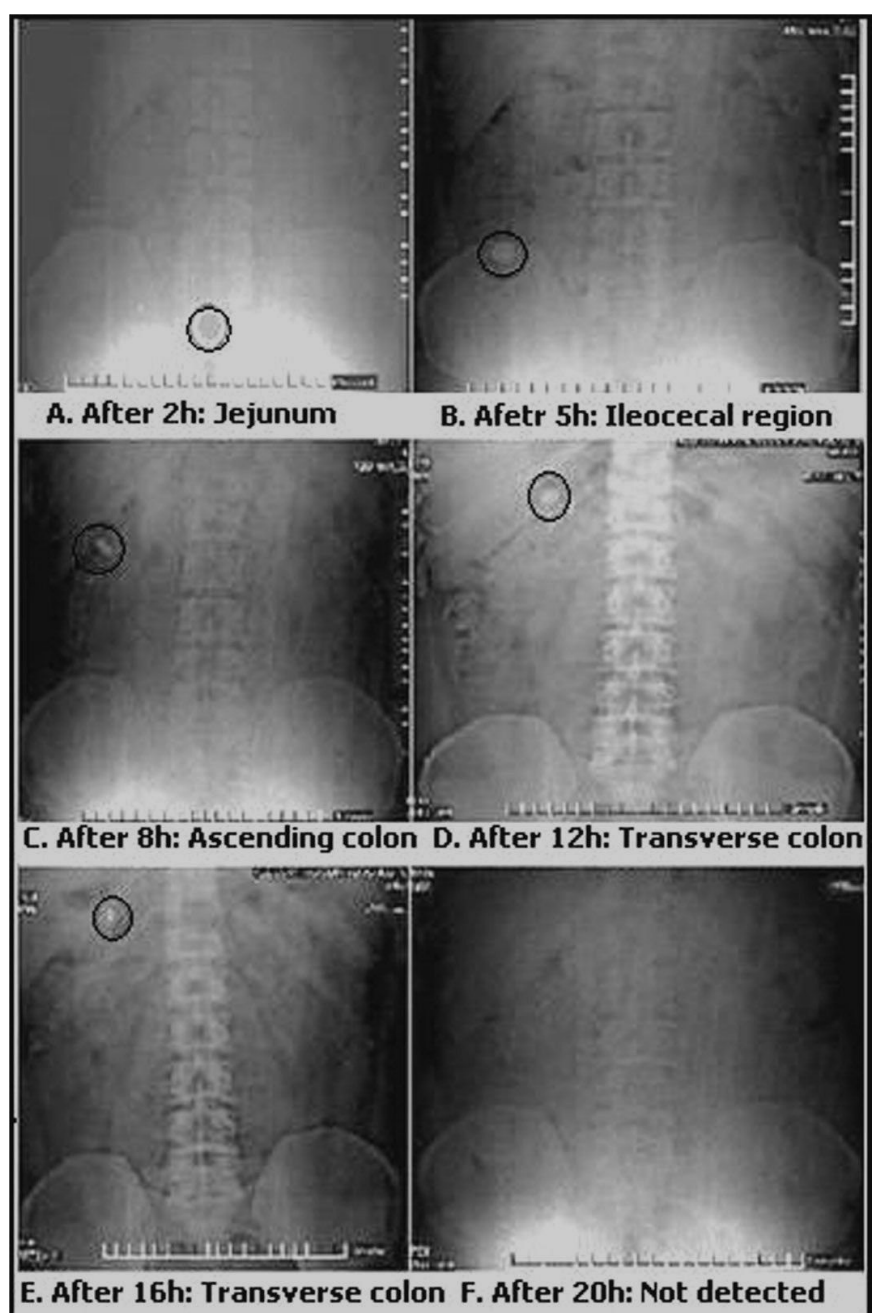

FIGURE 4 - The X-ray images at different time points showing tablet formulation CLH63 localization in the gastrointestinal tract.

The FTIR spectrum of 5-fluorouracil (A), formulation CLH63 before storage (B) and formulation CLH63 after storage (C) and placebo formulation of CLH63 (D) are represented in Figure 5. In case of FTIR spectra of 5-fluororuacil, bands at $3053 \mathrm{~cm}^{-1}, 3014 \mathrm{~cm}^{-1}$ and $2825 \mathrm{~cm}^{-1}$ are attributed to both aromatic and aliphatic $\mathrm{C}-\mathrm{H}$ stretching vibrations. A band at $1726 \mathrm{~cm}^{-1}$ represents the imide group stretching of heterocyclic ring. A band at $1661 \mathrm{~cm}^{-1}$ is due to the tertiary amide group stretching vibration. $\mathrm{N}-\mathrm{H}$ bending vibration is observed at $1517 \mathrm{~cm}$ ${ }^{1}$. A band at $1236 \mathrm{~cm}^{-1}$ shows $\mathrm{C}-\mathrm{N}$ stretching vibrations. 
The C-F stretching band was observed at $806 \mathrm{~cm}^{-1}$. When FTIR spectra of 5-fluorouracil were compared with FTIR spectra of compression coated tablet formulation CLH63 (before storage and after storage) there was no change in the position of the principal peaks/bands of 5-fluorouracil. This further confirms the integrity of pure drug 5-fluorouracil and their compatibility with the excipients of core as well as compression coated tablets.

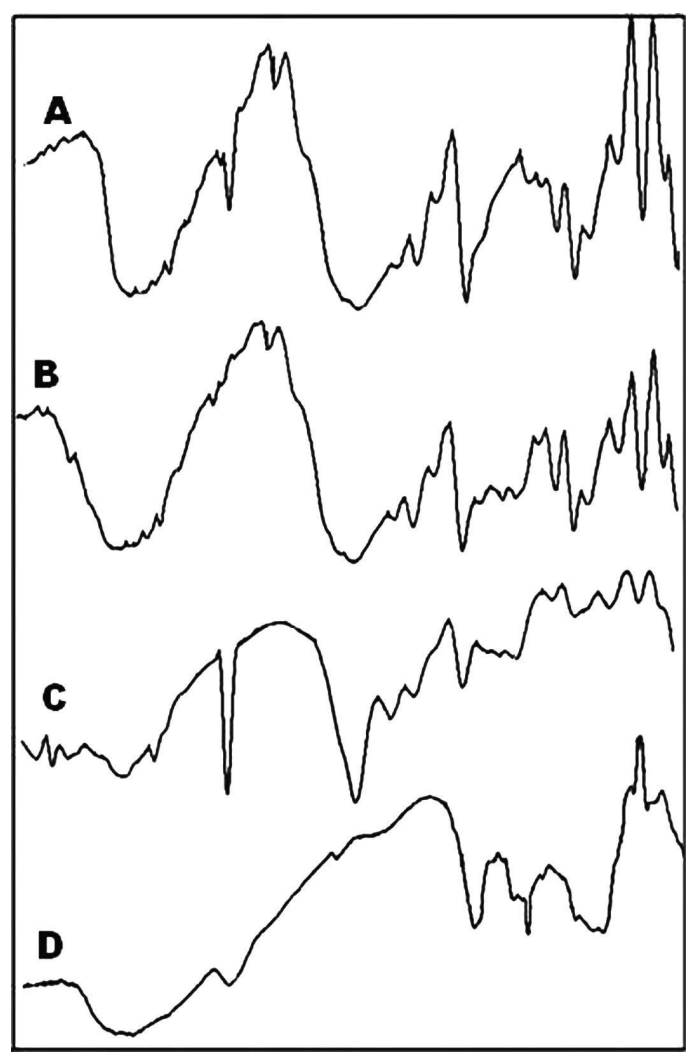

FIGURE 5 - FTIR spectra of 5-fluorouracil (A), formulation CLH63 before storage (B), formulation CLH63 after storage (C) and placebo formulation of CLH63 (D).

DSC curves of 5-fluorouracil (A), formulation CLH63 before storage (B) and formulation CLH63 after storage (C) and placebo formulation of CLH63 (D) obtained by constant rate heating (CRH) / constant rate thermal analysis (CRTA) method proposed by international confederation for thermal analysis and calorimetry (ICTAC) are shown in Figure 6. DSC curve of 5-fluorouracil showed a single sharp endothermic peak at $284.5^{\circ} \mathrm{C}$, which was ascribed to drug melting. The endothermic peak corresponding to melting point of 5-fluorouracil in formulation CLH63 before storage did not show any significant shift in the endothermic peak $285.68^{\circ} \mathrm{C}$. The DSC curve of formulation CLH63 after storing at $40{ }^{\circ} \mathrm{C} / 75 \% \mathrm{RH}$ for 6 months, the endothermic peak was slightly shifted to $275.17^{\circ} \mathrm{C}$. The findings of the DSC study further confirmed absences of interaction between 5-fluorouracil and excipients used in the core as well as compression coated tablets.

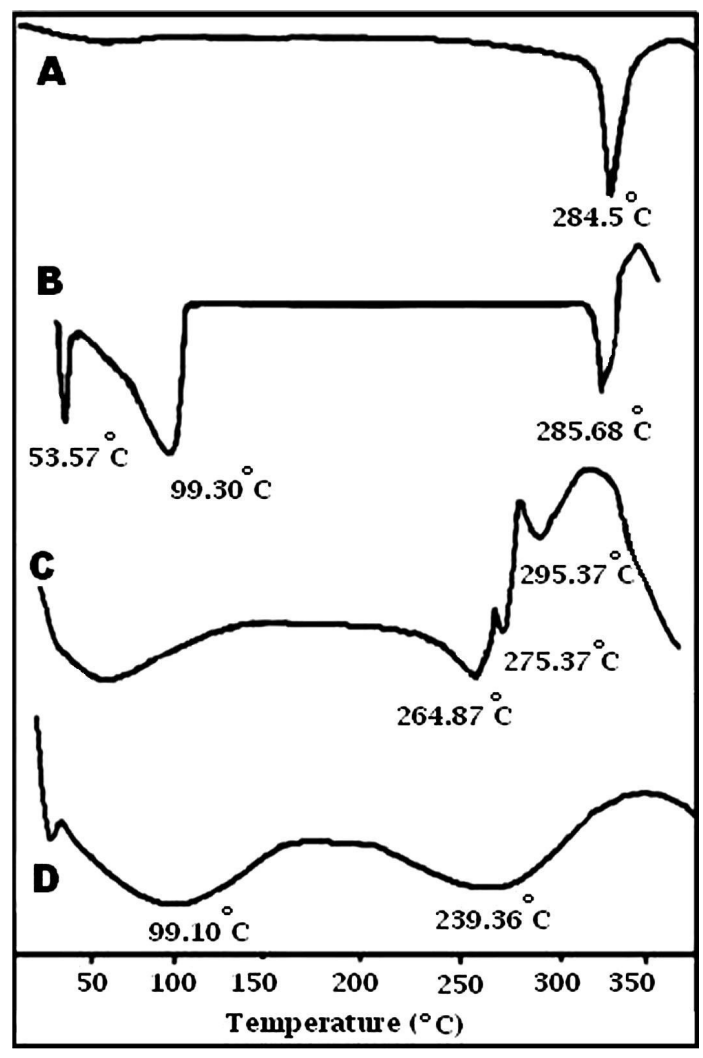

FIGURE 6 - DSC curves of 5-fluorouracil (A), formulation CLH63 before storage (B), formulation CLH63 after storage (C) and placebo formulation of CLH63 (D).

It was observed that, there was no significant change in hardness, friability, weight variation and drug content uniformity of the optimized batch formulation CLH63 after storage at $40{ }^{\circ} \mathrm{C} / 75 \% \mathrm{RH}$ for 6 months as shown in Table III. Figure 7 represents the in vitro release profile of 5-fluorouracil from optimized tablet batch formulation CLH63 after storage period of six months and there was no significant difference in the percent 5-fluorouracil released from the same formulation CLH63 before storage. This indicates that the formulation CLH63 could provide a minimum shelf life of 2 years (Mathews, 1999).

\section{CONCLUSION}

From the results of in vitro dissolution profile, we are able to conclude that fast disintegrating 5-fluorouracil core tablet compression coated with a coat formulation CLH63 found to be suitable for successful colonic delivery 


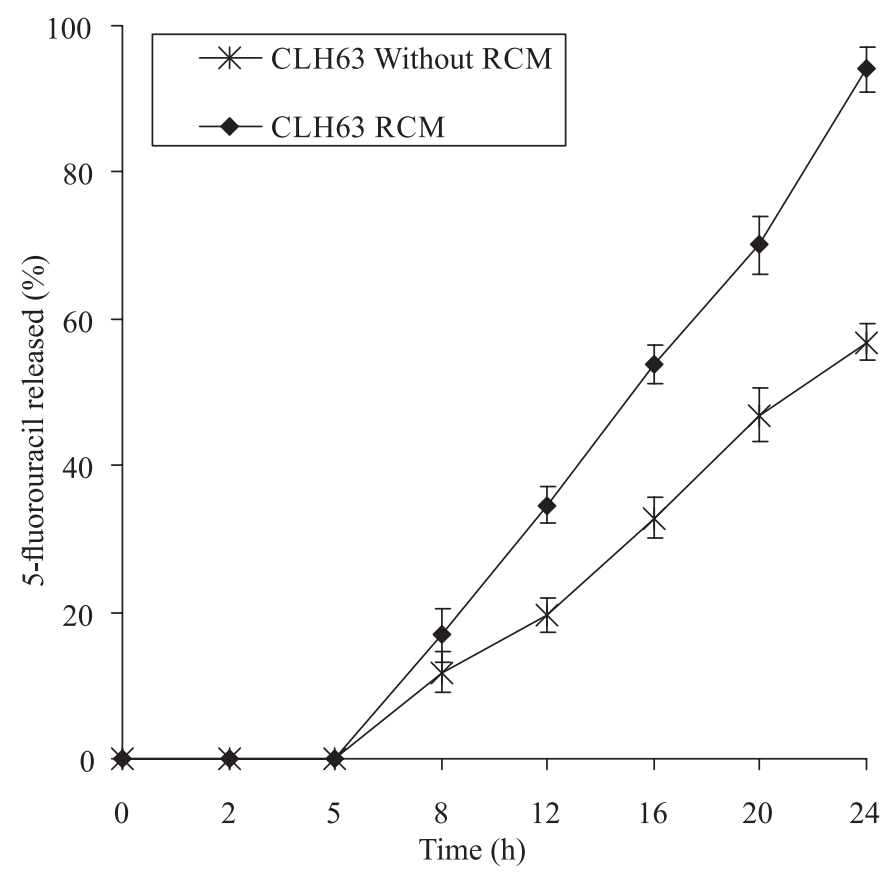

FIGURE 7 - Release profile of 5-fluorouracil from formulation CLH63 after storage at $40{ }^{\circ} \mathrm{C} / 75 \% \mathrm{RH}$ for 6 months.

of 5-fluorouracil without being released in physiological environment of stomach and small intestine. In vivo $\mathrm{X}$-ray studies using healthy human volunteers were also performed in which coat formulation CLH63 showed disintegration of the tablet in the ascending colon between 8 to 16 hours of post dose. Therefore, this study lays a basis for use of polysaccharide LBG along with HPMC for compression coating as one of the novel approaches for colonic delivery of 5-fluorouracil for the treatment of colon cancer.

\section{ACKNOWLEDGEMENTS}

Author is thankful to the Management, K.R.E.society's Karnataka College of pharmacy, Bidar, Karnataka (India) for extending research facility to carryout this research work. The authors report no conflicts of interest. The authors alone are responsible for the content and writing of this paper.

\section{REFERENCES}

AKHGARI, A.; AFRASIABI, G.H.; SADEGHI, H. Combination of inulin and time dependent polymethacrylates as a coating system to achieve colonic delivery of indomethacin. DARU J., v.17, p.199-208, 2009.
ASHFORD, M.; FELL, J.; ATWOOD, D.; SHARMA, H.; WOODHEAD, P. An in vitro investigation into suitability of $\mathrm{pH}$-dependent polymers for colon targeting. Int. J. Pharm., v.91, p.241-245, 1993.

BAOJAIN, W.; NINGYUN, S.; XIULI, W.; WEI, W. Characterization of 5-fluorouracil release from hydroxy propyl methyl cellulose compression-coated tablets. Pharm. Dev. Tech., v.12, p.203-210, 2007.

CHELLAN, V.R.; CHITHAMBARAM, M.; JOSEPH, A.J.; LENO, J. An in vitro and in vivo investigation into the suitability of bacterially triggered delivery systems for colon targeting. Chem. Pharm. Bull., v.50, p.892-895, 2002.

CALABRESI, P.; CHABNER, B.A. The pharmacological basics of therapeutics. 9.ed. New Delhi: McGraw-Hill, 1996. p.1225-1232.

DEMIROZ, F.T. In-vitro and in-vivo evaluation of mesalazineguar gum matrix tablets for colonic drug delivery. J. Drug Target., v.12, p.105-112, 2004.

DIASIO, R.B.; HARRI, B.E. Clinical pharmacology of 5-floropuracil. Clin. Pharmacokinet., v.16, p.215-237, 1989.

HUANG, S.I.; BANSLEBEN, D.A.; KNOX, J.R. Biodegradable polymers: chymotrypsin degradation of low molecular weight poly (esterurea) containing phenylalanine. J. Appl. Polym. Sci., v.2, p.429-437, 1979.

HAHN, R.G.; MOERTEL, C.G.; SCHUTT, A.J. A double blind comparison of intensive course of 5 - fluorouracil by oral versus intravenous route in the treatment of colorectal carcinoma. Cancer, v.35, p.1031-1035, 1975.

LACHMANN, L.; LIBERMAN, H.A.; KANIG, J.L. Theory and practice of industrial pharmacy. 3.ed. Bombay: Varghese Publishing House, 1987. p.293-345.

MUNIRA, M.K.; PUNDARIKAKSHUDU, K. Design, development and in vitro evaluation of sennosides tablets containing pectin:HPMC for colonic drug delivery. Indian J. Pharm. Sci., p.394-401, 2007.

MATHEWS, B.R. Regulatory aspects of stability testing in Europe. Drug Dev. Ind. Pharm., v.25, p.831-856, 1999.

MAYUR, M.P.; TEJAL, J.S.; AVANI, F.A. Design, development and optimization of a novel time and $\mathrm{pH}$-dependent colon targeted drug delivery systems. Pharm. Dev. Technol., v.14, p.62-69, 2009. 
OLUWATOYIN, A.O.; JOHN, T.F. In-vitro evaluation of khaya and albizia gums as compression coatings for drug targeting to colon. J. Pharm. Pharmacol., v.57, p.163-168, 2005.

PARK, K.; SHALABY, S.W.; PARK, H. Biodegradable hydrogels for drug delivery. Lancaster: Technomic publishing company, 1993. p.13-34.

POTTS, J.E.; CLENDIGS, R.A.; ACKARD, W.B.; WIGISCH, W.D. Colorectal cancer: molecules and population. J. Natl. Cancer. Inst., v.91, p.916-932, 1999.

R A M A P R A S A D, Y. V.; KR I S H I A H, Y.S.R.; SATYANARAYAN, S. In vitro evaluation of guar gum as a carrier for colonic specific delivery. J. Control. Rel., v.51, p.281-287, 1998.

RATNER, B.; GLADHILL, K.W.; HORBETT, T. Analysis of in vitro enzymatic and oxidative degradation of polyurethanes. J. Biomed. Mater. Res., v.22, p.509-527, 1998.
SAMIA, O.; BASMAH, A.; HANAN, R.; OMAIMAH, A.G. Colon-specific drug delivery for mebeverine hydrochloride. J. Drug Target., v.15, p.691-700, 2007.

SINHA, V.R.; MITTAL, B.R.; BHUTTANI, K.K.; RACING, K. Colonic drug delivery of 5- Fluorouracil: an in vitro evaluation. Int .J. Pharm., v.269, p.101-108, 2004.

VALLURI, R.; SIDDARAMAIAH, P.; KUMAR, T.M. Influence of natural polymers coating on novel colon targeting drug delivery systems. J. Mater. Sci. Mater. Med., v.19, p.21312136, 2008.

Received for publication on $02^{\text {nd }}$ March 2012 Accepted for publication on $03^{\text {rd }}$ January 2013 